

J. bio-sci. 17: 1-6, 2009

ISSN 1023-8654

http://www.banglajol.info/index.php/JBS/index

\title{
THE ANTIDIABETIC AND ANTILIPIDEMIC ACTIVITY OF AQUEOUS EXTRACT OF URTICA DIOICAL. ON TYPE2 DIABETIC MODEL RATS
}

\author{
M Das $^{1 *}$, B P Sarma ${ }^{1}$, A K A Khan², M Mosihuzzaman³ ${ }^{3}$ N Nahar ${ }^{3}$, L Ali ${ }^{4}$, A Bhoumik ${ }^{5}$, B Rokeya ${ }^{5}$ \\ ${ }^{1}$ Dept of Medicine, Govt. Ayurvedic College and Hospital, Guwahati, India ; '2Dept of Gastroenterology, \\ BIRDEM, Dhaka, Bangladesh; ${ }^{3}$ Dept of Chemistry, Dhaka University, Dhaka, Bangladesh; ${ }^{4}$ Dept of \\ Biochemistry and Cell Biology, BIRDEM, Dhaka, Bangladesh. ${ }^{5}$ Dept of Pharmacology, \\ BIRDEM, Dhaka, Bangladesh
}

\begin{abstract}
Context: To evaluate the anti-diabetic activity of Urtica dioica L. in type 2 diabetic model rats.

Objectives: The aim of this study is to explore the effect of water extract of $U$. dioica on glycemic status, body weight and lipidemic status in type2 diabetic model rats

Materials and Methods: The mature and fresh leaves of $U$. dioica was collected from the mountain range of Assam in India and the leaves extract was used at a dose of $1.25 \mathrm{~g}^{\mathrm{kg}}$ body weight. Type2 diabetes was induced by a single intraperitoneal injection of STZ to 48 hours old pups of Long Evans. Experiments for semi-chronic effects were done with continuous feeding of aqueous extract for 14 days at a dose of $1.25 \mathrm{~g}-\mathrm{kg}$ body weight type 2 diabetic male rats. Serum glucose was estimated by GOD-POD method, serum triglyceride and cholesterol by enzymatic-colorimetric methods.
\end{abstract}

Results: Water extract showed significant effect on lowering fasting serum glucose levels in type 2 diabetic model rats on $14^{\text {th }}$ day $(14.05 \pm 3.4 \mathrm{mmol} / \mathrm{l}$ in control vs $8.3 \pm 1.4 \mathrm{mmol} / \mathrm{l}$ in treated group, $p=$ 0.04). There was significant increase in the body weight of treated group in comparison to the control group ( $175 \pm 8 \mathrm{~g}$ in control vs in $168 \pm 9 \mathrm{~g}$ in treated group on 0 day, $\mathrm{p}=\mathrm{ns}$; $193 \pm 26 \mathrm{~g}$ in control vs in $185 \pm 25 \mathrm{~g}$ in treated group on $14^{\text {th }}$ day, $p=0.002$ ]. Beneficial effect was observed in lipid although the change was not statistically significant.

Conclusion: The results obtained in this study suggests that $U$. dioica has hypoglycemic and hypolipidemic activity in type 2 diabetic model rats. This may be due to the histological and functional improvement of $\beta$-cells with the consequence of improved insulinemic status.

Key words: hypoglycemic, hypolipidemic, Urtica dioica, diabetes mellitus

\section{Introduction}

Diabetes Mellitus is a clinical syndrome characterized by hyperglycemia caused by a relative or absolute deficiency of insulin at the cellular level. It is the most common endocrine disorder affecting mankind all over the world, prevalence of which is increasing day by day (Tong and Cockrum 2003). Traditional preparations from plant sources are widely used almost everywhere in the world to treat this disease. Therefore, plant materials are considered to be the alternative sources for finding out new leads for hypoglycemic agents. A total of more than 400 species were reported to display hypoglycemic effects, but few of them have been investigated scientifically (Bailey and Day 1989). The plant product under taken for anti-diabetic effect was Urtica dioica L. (UD), known as stinging nettle available in South Asian countries and much in Indian subcontinent. It is an annual herb of family Urticaceae, and is commonly known as medicinal herb for a long time in the world.

* Corresponding author 
There are very few papers available, which suggest the positive result for UD as anti-diabetic. The antidiabetic effect of this plant has been date back from the old writing of Avicenna. (Taylor 2006). Where as various researchers and scientist have contradictory result regarding the effect of UD as anti-diabetic. Farzami et al. (2003) observed that, there is induction of insulin secretion by a component of UD leaf extract in perfuse islets of Langerhans and its in vivo effect in normal and streptozotocin (STZ) induced diabetic rats. The chronic effect of the hydroalcoholic extract of UD leaves has no hypoglycemic effect (Golalipour et al. 2006). Whereas Golalipour and Khori (2007) find the hydroalcoholic extract of UD has hypoglycemic effect and protective activity of $\beta$-cells of langerhans in hyperglycemic rats. Oral and i.p. administration of hydroalcoholic extract of the plant showed a strong glucose lowering action only in streptozotocin (STZ) induced diabetic rats and normal rats did not show hypoglycemic effect (Garjani et al. 2006). Some studies also suggest that it have antihyperglycemic activity as aqueous extract (Bnouham et al. 2003). So it is difficult to establish its real action on diabetes. As there is contradictory views regarding the effect as hypoglycemic/antihyperglycemic activities of leaf extract of UD, the present study was done is to explore the effect of water extract of UD on glycemic status, body weight and lipidemic status in type2 diabetic model rats

\section{Materials and Methods}

Plant: The mature leaves of Urtica dioica were collected from the mountain range of Assam in India during the month of August'2008. Plants were grown absolutely naturally, without any synthetic fertilizer, insecticides or fungicides being used.

Preparation of the extract: Four $\mathrm{kg}$ of leaves were washed and dried hygienically under shade (inside a closed room) for 14-15 days in order to restore its medicinal properties. After drying completely the leaves were grinded to get powder $(900 \mathrm{~g})$, the powder dissolved with distilled boiled (hot) water ( $3.5 \mathrm{I})$ in a clean glass container and then cooled in room temperature. Then it was filtered through filter paper. The filtrate was collected and evaporated to dryness at reduced pressure using a rotary vacuum evaporator at a constant temperature of $45^{\circ} \mathrm{C}$. The extract was finally freeze-dried at $-55^{\circ} \mathrm{C}$. The dried sample $(86 \mathrm{~g})$ was stored in a reagent bottle at $2-8^{\circ} \mathrm{C}$ in a freezer. The water extract was utilized for biological experiment.

Animal: Adult male Long-Evans rats, weighing (180-250 g) was used through out the study. The animals were bred at BIRDEM Animal house maintained at ambient room temperature, feed with pellet diet and water ad libitum.

Induction of diabetes to the rats: Type2 diabetes was induced by a single i.p. injection of STZ at a dose of 90 $\mathrm{mg}$-kg body weight (BW) after dissolved in $0.1 \mathrm{M}$ citrate buffer, $\mathrm{pH} 4.5$ to $48-72 \mathrm{~h}$ old pups as described by Portha et al. (2001). Three months later they were used for experiments when they gained weight approximately $175-180 \mathrm{~g}$ after checking with an oral glucose load (2.5g-kg bw).

Experimental design: Type2 diabetic models rats were divided into 3 groups for experiment; (1) normal water control group $(n=6)$ fed with deionized water at a dose of $10 \mathrm{ml}-\mathrm{kg} \mathrm{BW}$; (2) NIDDM Glibenclamide positive control group $(n=6)$ treated with glibenclimed at a dose of $5 \mathrm{mg} / 10 \mathrm{ml}-\mathrm{kg}\left(9.9 \mathrm{ml} \mathrm{H} \mathrm{H}_{2} \mathrm{O}+0.1 \mathrm{ml}\right.$ Twin 20) BW (Ali et.al., 1993); (3) NIDDM treated group ( $n=8)$ fed with water extract of UD at a dose of $1.25 \mathrm{~g}$-kg BW (Ali et.al., 1993). The rats were fed for 14 days, with water extract of UD. Blood samples were drawn at 0 day by amputation of the tail tip and on $14^{\text {th }}$ day by decapitation.

Blood biochemistry: Semi-chronic effect on BW was measured at seven days interval i.e. $0^{\text {th }}$ day, $7^{\text {th }}$ day and $14^{\text {th }}$ day. Serum glucose was measured by Glucose Oxidase (GOD-PAP) method using micro-plate reader (Bio-Tec, ELISA). Serum lipid profile (Cholesterol, Triglycerides (TG) HDL- cholesterol) was measured by enzymatic colorimetric (Cholesterol Oxidase / Peroxidase) method, using autoanalyzer, AutoLab. Serum Low Density Lipoprotein (LDL) Cholesterol was calculated by Friedwald formula: $L D L$ Cholesterol $=$ Total Cholesterol - (1/5 TG + HDL Cholesterol) 
Data analysis: Data from the experiments were analyzed using the Statistical Package for Social Science (SPSS) for Windows. Values were expresses as mean \pm SD. Analysis of variance (ANOVA, Bonferroni Post Test) and pair t-test were done as the test of significance. $p \leq 0.05$ was considered as the minimal level of statistical significance.

\section{Results}

Injection of STZ to $48 \mathrm{~h}$ old pups (producing type2 diabetic models) resulted in diabetes characterized by hyperglycemia (fasting blood glucose level ranges between $8.0 \pm 2.5$ to $11.5 \pm 1.5$ ) after 3 months of injection. At the initial day of the experiment, fasting blood glucose levels were only slightly higher in type2 model rats, indicating the presence of functioning $\beta$ cells. But after 14 days of chronic feeding, UD water extract has significant effect $(p=0.044)$ on lowering of fasting glucose levels of type2 diabetic rats (serum glucose level, $8.3 \pm 1.4 \mathrm{mmol} / \mathrm{l}$ ) compared with control group (serum glucose level, mmol/l, $14.05 \pm 3.4$ ) (Table 1).

Body weight of each rat was taken at seven days interval (Table 1). There was increased in BW of all groups of rat (control, Glibenclamide and extract treated) when compared with the initial value ( 0 day value). The body weights of Glibenclamide and UD extract treated rats were significantly high on the $14^{\text {th }}$ day value $(p=$ $0.012)$ when compared to the $7^{\text {th }}$ day value $(p=0.002)$.

The effect of $U$. dioica water extract on body weight of type2 diabetic rats during 14 days of chronic oral administration was observed. Body weight of each rat was taken at seven days interval (Table 2). As it is seen from the table, there was increased in body weight of all groups of rats (control, Glibenclamide and extract treated) when compared with the initial value ( 0 day value). The body weights of Glibenclamide and UD extract treated rats were significantly high on the $14^{\text {th }}$ day value when compared to the $7^{\text {th }}$ day value.

Effect of UD water extract on lipidemic status of type2 diabetic model rats was observed and there was no significant change in the total cholesterol level among all the groups after 14 days of consecutive feeding. The mean total cholesterol levels were $63.00 \pm 9.00$ in extract fed group, compared with $72.00 \pm 6.00$ in the control group of 14 day (Table 2). There is slight decreased cholesterol level (1.56\%) in the extract treated group in compare with initial value and $12.5 \%$ decreased of cholesterol level in comparing with the control group of 14-day value. Serum triglyceride level was decreased in extract fed group compared with 0 day value an (10.1\%), nd compared to 14 -day control group there were $21.93 \%$ decreased.

The HDL level was increased (5.7\%) in extract fed group in compared with the initial day value. There were no significant in LDL level on 14 day semi-chronic experiment in all the groups, but there were $11.12 \%$ decreased in extract treated group compared with 0 day and $33.3 \%$ decreased in compared with the control group on 14 day value (Table 2).

Table 1. Effect of Urtica dioica water extract on fasting glucose level and body weight in type2 diabetic model rats.

\begin{tabular}{|c|c|c|c|}
\hline Group & $W C(n=6)$ & Gliben $(n=6)$ & Extract treated $(n=8)$ \\
\hline Glu_0_day(mMol/l) & $9.6 \pm 0.2$ & $8.8 \pm 1.20$ & $9.5 \pm 1.3$ \\
\hline Glu_14 $4^{\text {th }}$ day $(\mathrm{mMol} / \mathrm{l})$ & $14.1 \pm 3.4$ & $6.2 \pm 1.60^{*}$ & $8.3 \pm 1.4^{*}$ \\
\hline$\%$ increase/decrease (-) _0-14 day & 46.4 & -29.31 & -9.43 \\
\hline BW_ 0 day $(g)$ & $175.0 \pm 8.0$ & $175.0 \pm 5.0$ & $168.0 \pm 9.0$ \\
\hline$B W_{-} 7^{\text {th }}$ day $(\mathrm{g})$ & $174.0 \pm 20.0$ & $180.0 \pm 16.0$ & $165.0 \pm 17.0$ \\
\hline BW_ $14^{\text {th }}$ day $(\mathrm{g})$ & $193.0 \pm 26.0$ & $190.0 \pm 21.0$ & $185.0 \pm 25.0$ \\
\hline$\%$ increase/decrease (-) _0-14 day & 10.0 & 9.0 & 10.0 \\
\hline
\end{tabular}

WC= Water control, Gliben= Glibenclamide, $U$. dioica= Urtica dioica water extract. Between group comparison was done using one way ANOVA with post Hoc Bonferroni test. ${ }^{*} p<0.01,{ }^{* *} p<0.001 . n=$ number of rats. 
Table 2. Effect of Urtica dioica extract on serum cholesterol, TG, HDL and LDL level in type2 diabetic model rats.

\begin{tabular}{|c|c|c|c|}
\hline Group & $W C(n=6)$ & Gliben $(n=6)$ & Extract treated $(n=8)$ \\
\hline $\mathrm{CH} \_\mathrm{O}(\mathrm{mg} / \mathrm{dl})$ & $60.0 \pm 16.0$ & $67.0 \pm 18.0$ & $64.0 \pm 10.0$ \\
\hline CH_14(mg/dl) & $72.0 \pm 6.0$ & $67.0 \pm 9.0$ & $63.0 \pm 9.0$ \\
\hline$\%$ increase/decrease (-) _0-14 day & 20.0 & 0 & -1.57 \\
\hline TG_O(mg/dl) & $87.0 \pm 51.0$ & $87.0 \pm 19.0$ & $99.0 \pm 19.0$ \\
\hline TG_14(mg/dl) & $114.0 \pm 33.0$ & $83.0 \pm 9.0$ & $89.0 \pm 15.0$ \\
\hline$\%$ increase/decrease (-) _0-14 day & 31.0 & -4.6 & -10.1 \\
\hline HDL_O(mg/dl) & $35.0 \pm 7.0$ & $36.0 \pm 8.0$ & $35.0 \pm 7.0$ \\
\hline HDL_14(mg/dl) & $37.0 \pm 5.0$ & $39.0 \pm 3.0$ & $37.0 \pm 2.0$ \\
\hline$\%$ increase/decrease (-) _0-14 day & 5.7 & 8.3 & 5.2 \\
\hline LDL_O(mg/dl) & $7.0 \pm 1.9$ & $14.0 \pm 2.8$ & $9.0 \pm 1.2$ \\
\hline LDL_14(mg/dl) & $12.0 \pm 4.0$ & $11.0 \pm 7.0$ & $8.0 \pm 11.0$ \\
\hline$\%$ increase/decrease (-) _0-14 day & 71.4 & -21.4 & -11.1 \\
\hline
\end{tabular}

WC $=$ Water control, Gliben= Glibenclamide, $U$. dioica= Urtica dioica water extract. Between groups comparison was done using one way ANOVA with post Hoc Bonferroni test. ${ }^{*} p<0.01,{ }^{*} p<0.001 . n=$ number of rats

\section{Discussion}

The rapidly increasing prevalence of diabetes throughout the world will continue to challenge the scientists and clinicians in refining existing therapies and developing new approaches to counter this devastating disease. The scope for the discovery and development of new antidiabetic therapies from nature/plants is vast and merits corresponding attention. Although oral hypoglycemic agents and insulin is the mainstay of treatment of diabetes and are effective in controlling hyperglycemia, they have well known side effects and fail to significantly alter the course of diabetic complications (Rang et al. 1991). As the knowledge of heterogeneity of this disorder increases, there is needed to look for more efficacious agents with lesser side effects. Moreover, the existing drugs do not modify the course of diabetic complications. In relation to plants also, barring a few studies (Grover et al. 2000, Srivastava et al. 1988, Karunanayaka et al. 1990, Mostofa et al. 2007, Ahmed et al. 2005), most of the studies have not assumed the impact of these plants on the course of diabetes and its complications, particularly the macrovascular pathologies. Since inflammation plays an important role in the pathogenesis of diabetes so exploration of new anti-inflammatory compounds from the nature is also an important task as various synthetic anti-inflammatory drugs produce solemn adverse effects in different vital organs in the body.

In the present investigation, it was found that in type2 diabetic model rats, STZ produced significant increase in fasting glucose levels $(9.3 \pm 0.9)$. Injection of STZ produces fragmentation of DNA of pancreatic $\beta$-cells, which stimulates poly (ADP-ribose) and depletes NAD. Ultimately it leads to destruction of $\beta$-cells and it is evidenced by hyperglycemia and hypoinsulinemia (Goyal et al. 1999). Treatment with U. dioica significantly reduced the serum glucose levels for $14^{\text {th }}$ days value in type 2 compared the control Group.

Dyslipidemia is an important risk factor for atherosclerotic complications of diabetes. Hypercholesterolemia and hypertriglyceridemia have been reported to occur in STZ induced diabetic rats (Sharma et al. 1997). Apart from blood glucose lowering activity of UD, changes in lipid profile have also been observed. Regarding total cholesterol level, no significant reduction was found, but there was a reduction of $6 \%$ compared with final day glibenclamide value and $12.5 \%$ compared with control in type2 diabetic model rats on the $14^{\text {th }}$ day. The protective HDL-cholesterol level was found to be increased by $5.71 \%$ in extract fed 
group in compared with the initial day value by UD water extract. As dyslipidemia is very common among diabetics, so improvement in the lipid abnormalities must play beneficial role in inhibiting such complications. UD water extract seem to be mediated through improvement in $\beta$-cell morphology and/or function. Prevention of ongoing $\beta$-cell damage, recovery of partially damaged $\beta$-cells, regeneration of new cells and stimulation of insulin secretion in functional cells is among the alternate possibilities induced by the water extract.

\section{Conclusions}

Water extract of Urtica dioica leaves improves the glycemic and lipidemic status and induced improvement of glycemic and lipidemic levels in type2 diabetic rats, which is mediated by the central effect on the histological and/or functional status of pancreatic $\beta$-cells.

\section{Acknowledgements}

We gratefully acknowledged the financial and logistic supports provided by the international program in the chemical Science (IPICS), Uppsala University Sweden and Asian Network of Research on Anti-diabetic Plants Materials, Dhaka to perform their study.

\section{References}

Ahmed S, Awal MA, Rahman MM, Mostofa M. 2005. Comparative efficacy of neem and karela with insulin and glibenclamide on lipid profile in rabbit (Oryctolagus cuniculus). J Anim Vet Adv 4, 103-106. doi:10.3329/bjvm.v5i1.1324

Bailey CJ, Day C. 1989. Traditional plant medicines as treatments for diabetes. Diabetes Care 12, 553-564. doi:10.2337/diacare.12.8.553

Bnouham M, Merhfour FZ, Ziyyat A, Mekhfi H, Aziz M, Legssyer A. 2003. Antihyperglycemic activity of the aqueous extract of Urtica dioica. Fitoterapia 74, 677-681. doi:10.1016/S0367-326X(03)00182-5

Farzami B, Ahmadvand D, Vardasbi S, Majin FJ, Khaghani SH. 2003. Induction of insulin secretion by a component of Urtica dioica leave [sic] extract in perfuse [sic] islet of langerhans and its vivo effects in normal and streptozotocin diabetic rats. J Ethnopharm 89, 47-53. doi:10.1016/S0378-8741(03)00220-4

Garjani A, Fathi Azad F, Maleki N, Ranjdost S. 2006. Study of hypoglycemic activity of the hydroalcoholic extract of Urtica dioica in normal and diabetic rats. J Fac Pharm Tabriz Univ Med Sci 11(2), 65-69.

Goyal RK. 1999. Hyperinsulinemia and insulin resistance in hypertension: differential effects of antihypertensive agents. Clin Exp Hypertens 21, 167-179. doi:10.3109/10641969909068659

Grover JK, Vats V, Rathi SS. 2000. Antihyperglycemic effect of Eugenia jamblona and Tinospora cordifoloia in experimental diabetes and their effects on key-metabolic enzymes involved in carbohydrate metabolism. J Ethnopharm 73, 461-470. doi:10.1016/S0378-8741(00)00319-6

Karunanayak EH, Jeevathayaparam S, Tennekoon KH. 1990. Effect of Momordica charantia fruit juice on streptozotocininduced diabetes in rats. J Ethnopharm 30, 199-204. doi:10.1016/0378-8741(90)90008-H

Laakso M, Lehto S. 1997. Epidemiology of macrovascular disease in diabetes. Diabetes Research 5, 294-315.

Golalipour MJ, Khori V, Ghafari S, Gharravi AM. 2006. Chronic effect of the hydroalcoholic extract of Urtica dioica on regeneration of $\beta$-cells of hyperglycemic rats. Pak J Biol Sci 9 (8), 1482-1485. doi:10.3923/pjbs.2006.1482.1485

Golalipour MJ and Khori V. 2007. The protective activity of Urtica dioica leaves on blood glucose concentration and $\beta$-cell in Streptozotocin-diabetic rats, Pak J Biol Sci 10(8), 1200-1204. doi:10.3923/pjbs.2007.1200.1204 
Mostofa M, Choudhury ME, Hossain,MA, Islam MZ, Islam MS, Sumon MH. 2007. Antidiabetic effects of Catharanthus roseus, Azadirachta indica, Allium sativum and Glimepride in experimentally diabetic induced rat. Bangladesh $\mathrm{J}$ Vet Med 5, 99-102.

Portha B, Giroix MH, Serradas P, Movassat J, Bailbe D, Kergoat M (2001) The neonatally streptozotocin-induced (n-STZ) diabetic rats, a family of NIDDM models. In: Sima AAF, Shafrir (eds) Animal Models of Diabetes: A Primer [pp.247268], Harwood Academic Publishers, Armsterdam.

Tong PCY, Cockrum CS (2003) Diabetes and its historical and social context: The epidemiology of type2 diabetes, In: Pickup JC \& Williams G (eds) Textbook of Diabetes ( $3^{\text {rded}}$ ) Blackwell Science Ltd. Massachusetts, USA. 6.1-6.14pp. doi:10.1002/0470862092.d1116

Rang HP, Dale MM, Rittar JM (1991) The endocrine system Pharmacology. In: Pharmacology. Longman Group Ltd., UK. pp.504-508.

Sharma SR, Dwivedi SK, Swarup D (1997) Hypoglycemic, antihyperglycemic and hypolipidemic activities of Caesalpinia bonducella. J Ethnopharm 58, 39-44. doi:10.1016/S0378-8741(97)00079-2

Srivastava V, Ventatakrishna-Bhatt H, Verma Y (1988) Effect of Momordica charantia Linn. aquous extract on cataract genesis in murrin alloxan diabetes. Pharm Res Comm 20, 201-209. doi:10.1016/S0031-6989(88)80041-9

Taylor L (2006) Raintree Nutrition Tropical Plant Database. Updated February 21, 2006. Available at http://www.raintree.com/nettles.htm. Last updated 20-3-2010. 